\title{
FULFILLING THE REQUIREMENTS FOR EXPORT OF METAL INDUSTRY PRODUCTS FROM SERBIAAND BOSNIA AND HERZEGOVINA CROSS-BORDER AREA TO EU MARKET
}

\author{
Dr Vesna Spasojević-Brkić \\ University of Belgrade, Faculty of Mechanical Engineering, Belgrade, Serbia \\ Dr Zorica Veljković \\ University of Belgrade, Faculty of Mechanical Engineering, Belgrade, Serbia \\ Tamara Golubović \\ University of Belgrade, Faculty of Mechanical Engineering, Belgrade, Serbia
}

Exporting to European Union market includes free exchange of people, goods and services as well as wide range of opportunities for companies, but also includes many difficulties and requirements which need to be fulfilled. As exporting is a difficult challenge for metal industry companies in Serbia and Bosnia and Herzegovina, this study included 20 small and medium sized companies from cross-border area - Zlatibor and Sarajevo districts, which have traditionally been export oriented, in order to improve activities regarding fulfilling the requirements for export of metal industry products from given regions. Analyses were conducted on statistically significant differences between influential parameters on fulfilling the requirements for export of metal industry products in cross border area of Serbia and BIH to EU market, financial standings and investment in the employee development, implementation of New Approach directives, implementation of management system standards and other. It was found that the largest issue in both Sarajevo and Zlatibor district are financial resources for fulfilling the requirements, while most influential obstacle is lack of government support and incentives. Recommendations are given to metal industry companies in both districts, based on the conducted empirical research. The research on fulfilling requirements for export of metal industry products to the EU market in the cross-border area of Serbia and BIH gives opportunity for companies in those areas to be connected and motivated to become more competitive, by using and exchanging modern knowledge and skills, European procedures and standards, raising the technological level and mutual promotional appearances.

Key words: Export requirements, EU market, Sarajevo and Zlatibor districts, Mann-Whitney U*-Test

\section{INTRODUCTION}

European Union (EU) market model implies free exchange of people, goods and services. This includes wide range of opportunities for anyone who exports products and services to EU market, but also includes many difficulties that have to be overcome in order to fulfill all requirements that go along with exporting goods to EU. Even though it is a challenging task, overcoming those difficulties can result in strengthening and better coordination of market monitoring and control, strengthening legislative system and its application on the national level, securing coherence rules for work of notified bodies, secure that accreditation stays in public domain in order to avoid further multiplication in area of control of the products, and much more $[05,26]$.

In the European Union document White Paper Preparation of the Associated Countries of Central and Eastern Europe for Integration into the Internal Market of the Union, there are requirements and measures which these countries have to adopt in each sector of their internal market. According to requirements from the White Paper countries of Central and Eastern Europe have to align their legislations, standards and practice in 23 different sectors. Second chapter of White Paper contains information on free exchange and safety of industrial products. The principle 
of mutual recognition of goods that are legally placed on the market, technical harmonization of legislation and mechanisms to prevent new trade barriers, are instruments that ensure the free exchange of goods in the EU [18].

According to [08] regarding to export to the EU market, largest influence on the companies have proccess of adjustment of national legislation with EU legislation, primarily in the sector of technical requirements and safety requirements for the products. With adjustment of their business to the new directives and regulations, domestic companies actually bring their competitiveness and quality of products and services on the higher level, making them more resistant to the influence of competition that comes along with opet market.

The import/export ratio in Serbia, despite the export continuous increase, still is not higher than $72 \%$ in $2013 / 9 /$.

The import/export ratio in $\mathrm{BIH}$ is even worse, not being higher than $53 \%$ [20].

Fulfilling the requirements for export to the EU market is difficult challenge for metal industry companies in Serbia and BIH. Metal industry in Serbia and BIH was very developed in former Yugoslavia and participated in GDP with almost
$40 \%$, while both countries share strong commitment towards EU integration. Serbia was granted the EU candidate status on 1st March 2012. Following the active and constructive efforts towards a visible and sustainable improvement of relations with Kosovo, the European Council decided to open accession negotiations with Serbia on 28th June 2013. On 16th June 2008 Bosnia and Herzegovina and the European Commission signed the Stabilization and Association Agreement (SAA). By signing the agreement the EU recognized the efforts of Bosnia and Herzegovina in the path of EU integrations [02].

Metal industry was once the foundation of Serbian industry, having high levels of capacity utilization /19/ while today it can be characterized with significant number of insufficiently strong companies which are in the process of reorganization, but still with growing number of examples with efficiency and productivity improvement. That is, there is an increasing number of small and medium sized companies that make excellent business results. However, generally speaking, results of the whole sector in 2008 have been influenced by the global economic crisis, by decline in the industrial production and construction, as well as by metals and semi-finished metal products price reduction $[12,17]$.

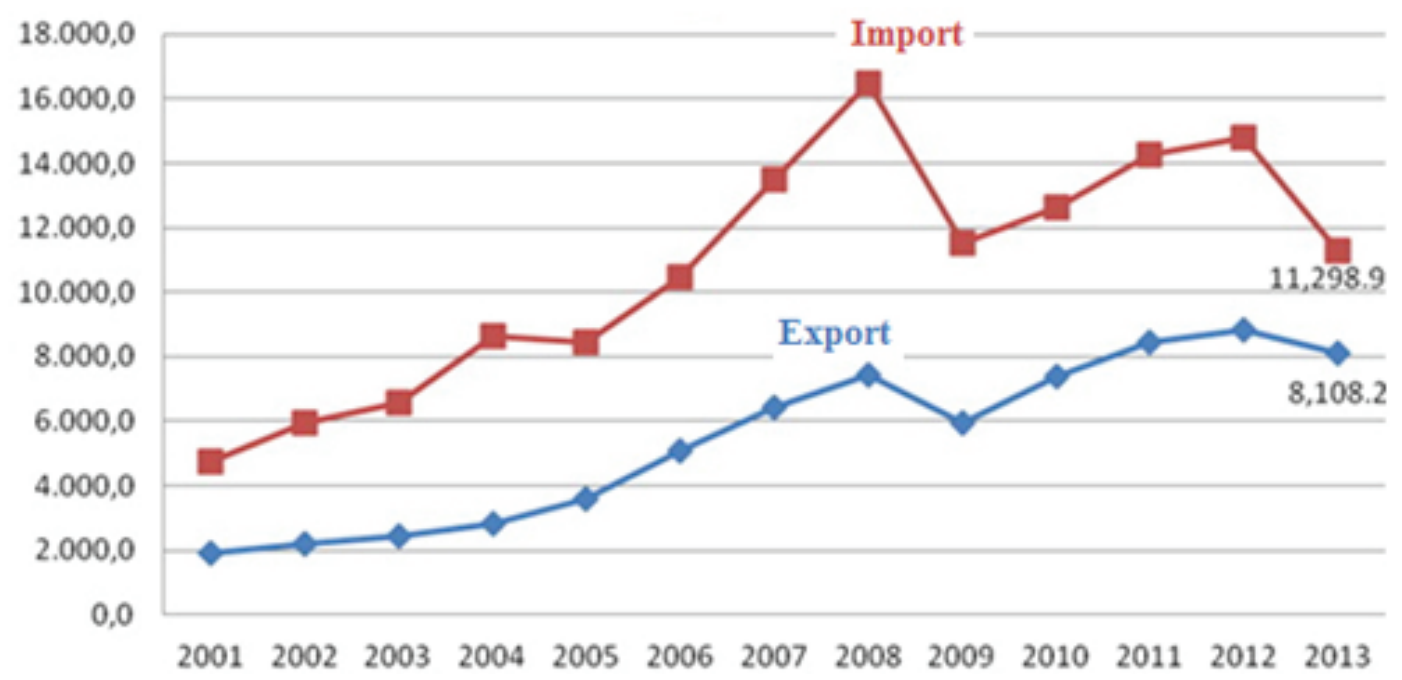

Figure 1: Serbian economics of foreign trade from 2001 to 2013, in millions of euros [09]

BIH metalworking industry continuously has surplus and represents the largest export sector in Bosnia and Herzegovina that counts around $38 \%$ of the whole BIH export. Leading export product from this sector are metals, more precisely, aluminum and steel. Following is the automotive industry, with stabile growth and significant de- velopment potential. Metal products also have significant development potential [15].

Metal industry sectors of Serbia and $\mathrm{BIH}$ are subjected to different classifications of work areas, even though they refer to the same types of products. Metal industry sector of Serbia includes [10]: 
- Extracting metal ore

- Production of base metals

- Production of standard metal products, not including machines or devices

- Production of machines and devices

- Production of electric and optic devices

- Production of traffic means (motor vehicles, electronic, and electric equipment for MW, trailers, motor vehicle body, etc.)

- Production of other traffic means (ships, locomotives, airplanes, space aircrafts, motorbikes, military, vehicles, etc.)

- Other processing industry (metal industry includes only recycling of used raw materials in this section)

On the other hand, metal industry sector in $\mathrm{BIH}$ lists its sub-sectors as follows [6]:

- Metals and metal products (pipes, profiles, etc.)

- Electronic equipment

- Machines and devices

- Transportation vehicles (automotive industry) The Strategy for Development of Competitive and Innovative SMEs Serbia 2008-2013 envisages the development of a knowledge-based economy, which creates a strong and export oriented SME sector that contributes to an increase in the standard of living in Serbia [22]. As for the territory of Bosnia and Herzegovina, Strategy for development SMEs in $\mathrm{BIH}$ for 2009-2011 predicts improvement of business environment in $\mathrm{BIH}$, raising competitiveness of SMEs and support to increasing export possibilities as the main measures within priority of economic development [14].

There is a large number of barriers and obstacles preventing entrant companies from being established and successful in EU market/3/. From before, canton of Sarajevo and Zlatibor district are recognizable by metal complex, which intends to adjust to new conditions and challenges of international market.

It is important to define exact situation with implemented standards and directives in companies from these districts, and to define obstacles and barriers that these companies stumble upon in the process of fulfilling the requirements for export of metal industry products to EU market. In order to do so, for this study needed data from companies sample were collected and analyzed.

\section{SAMPLE AND METHODS}

On the cross border territory covering Sarajevo Macro Region and Zlatibor County there are 150 SMEs dealing in metal sector. This study included 20 small and medium-sized companies, ten from each region, which have traditionally been export oriented, in order to improve activities regarding fulfilling the requirements for export of metal industry products from given regions $\neg / 12 /$. All of the companies from this specified sample agreed to participate in the survey. Survey of the companies was conducted via e-mail query, using Google docs (survey instrument can be seen on the link https://docs.google.com/forms/d/1/49 YuzgCebrUigrAQHYwR36SJI9OKj3As01T3Od2 qQM/viewform).

Company size is determined by the number of employees, total revenue and asset value /24/. Primary analyses were fist conducted on the basic data [21] which refer to descriptive statistics of the number of employees in the companies from both regions. Results are shown in Table 1.

The range of the number of employees is far greater in the Zlatibor district, where surveyed production companies showed numbers ranging from 5 to 1500 employees. In Sarajevo area this range was only from 12 to 97 employees.

Out of all companies that participated in the survey in the Zlatibor district, $70 \%$ of the companies were from sector of standard metal products, not including machines and devices, $20 \%$ were from sector of basic metals, and $10 \%$ from sector of electronic and optic devices. In Sarajevo district, $50 \%$ of the companies were classified as metals and metal products, $20 \%$ as machines and devices and transportation vehicles, and $10 \%$ as electronic equipment.

Table 1. Descriptive statistics of the number of employees in Sarajevo and Zlatibor districts

\begin{tabular}{|l|c|c|c|c|c|c|c|}
\hline & Valid N & Mean & Median & Min & Max & Std.Dev. & Coef.Var. \\
\hline Zlatibor district & 10 & 174.500 & 64.5 & 5 & 1005 & 307.61 & 176.28 \\
\hline Sarajevo district & 10 & 39.900 & 29.5 & 12 & 97 & 27.68 & 69.38 \\
\hline
\end{tabular}


Implementation of ISO management standards in Sarajevo Macro Region and Zlatibor County is also important predecessor of export. Anderson et al. [04] found that export to Europe and elsewhere increases U.S. firms' likelihood of seeking ISO 9000, while Corbett [13] concluded that supply chain pressures related to export flows contributes to global diffusion of ISO 9000 . According to the number of QMS certificates, Serbia takes the 54th position in the world, while Bosnia and Herzegovina has even lesser number of certificates in proportion to the population number $[17,25]$ even though applying ISO 9000 makes way to improvement of business performance [23]. For this reason, an analysis was conducted regarding the matter of implementation of the ISO 9001:2008 standard. Results show that the situation with standard is similar for both districts, whereby $70 \%$ of the companies have implemented the standard, $20 \%$ of the companies are in the phase of preparation or implementing the standard, while $10 \%$ of the companies don't have ISO 9000 standard.

Since Christmann and Taylor [11] and Albuquerque et al. [01] found that exports to more-developed countries increase the likelihood of ISO 14000 certification, as well as for importance of product safety [27], application of standard ISO 14000 and ISO 18000 was examined in this survey, too. Even though there aren't any statistically significant difference between the two districts, diagram in the Figure 2 shows that in Zlatibor district $40 \%$ of the companies have one of these standards while in $20 \%$ of the companies standard is in preparation. On the other hand in Sarajevo district not one company has those additional standards but in $30 \%$ of them one of these standards is in preparation or implementation phase.

Data collected on differences between influential parameters on fulfilling the requirements for export of metal industry products in cross border area of Serbia and BIH to EU market in this survey were nonhomogeneous (variation coefficients were greater than $30 \%$ ). Therefore nonparametric tests were used, such as Mann-Whitney U*-Test.

\section{RESULTS AND DISCUSSION}

Statistically significant differences between influential parameters on fulfilling the requirements for export of metal industry products in cross border area of Serbia and BIH to EU market

Regarding the fact that in further analysis data were nonhomogeneous (variation coefficients were greater than $30 \%$ ), Mann-Whitney $U^{*}$-Test is used.

\section{Export of small and medium sized compa- nies from Sarajevo and Zlatibor district metal complex}

Sarajevo district companies export far more than companies from Zlatibor district, as shown in Table 2 and Figure 3.

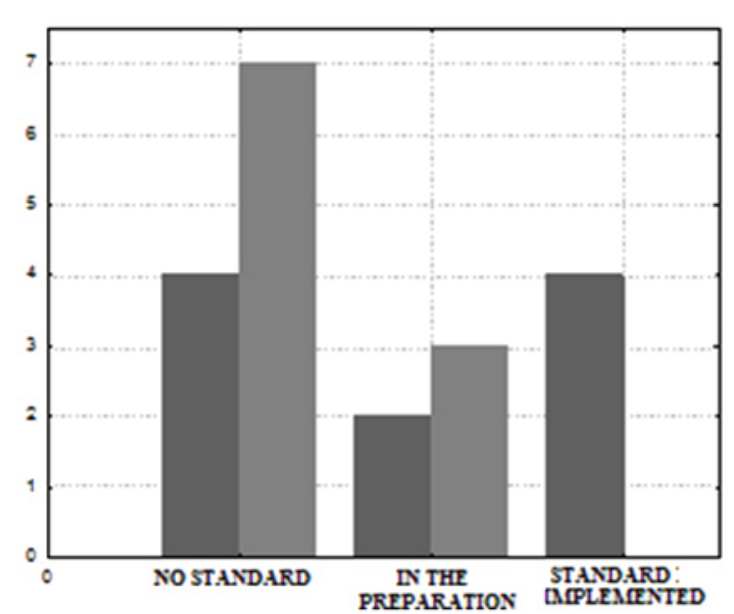

Figure 2: Application of standards ISO 14000 and ISO 18000 in Sarajevo Macro Region and Zlatibor County

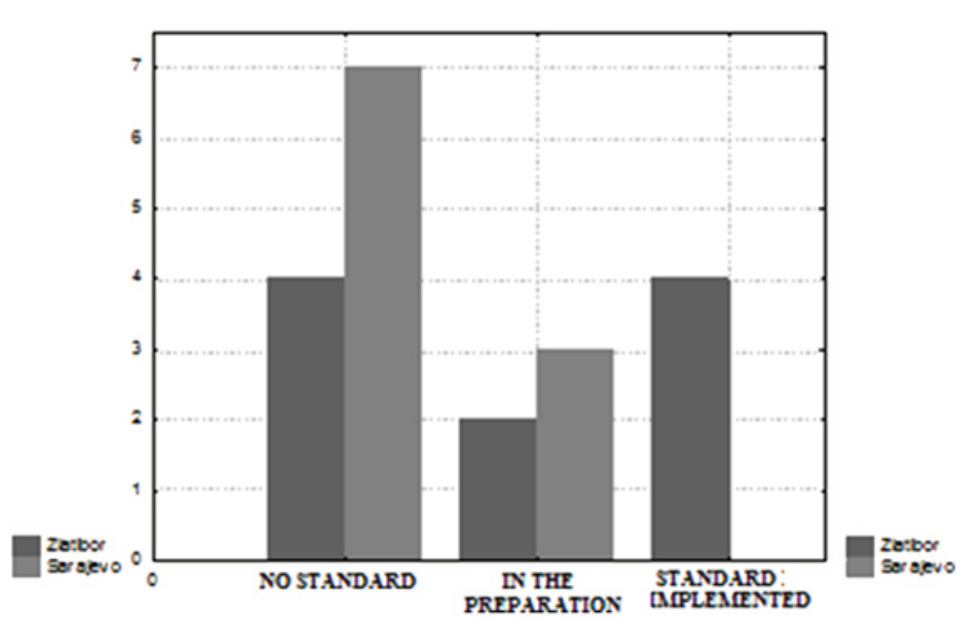

Figure 3: Export data for companies from Sarajevo and Zlatibor districts 
Table 2: Exporting differences between Sarajevo and Zlatibor district companies

\begin{tabular}{|r|c|c|c|c||c|}
\hline & ZL & & SA & & p-level \\
\hline \hline Export & ZL & $<$ & SA & $* *$ & 0.008 \\
\hline
\end{tabular}

Table 3: Data on financial standings and investment in the employee development in Zlatibor and Sarajevo district

\begin{tabular}{|r|l|l||c|r|r|}
\hline & $\mathrm{ZL}$ & & $\mathrm{SA}$ & $\mathrm{p}$-level \\
\hline Finance & $\mathrm{ZL}$ & $>$ & $\mathrm{SA}$ & ${ }^{*}$ & 0.046 \\
\hline Employee development & $\mathrm{ZL}$ & $=$ & $\mathrm{SA}$ & $\mathrm{ns}$ & \\
\hline
\end{tabular}

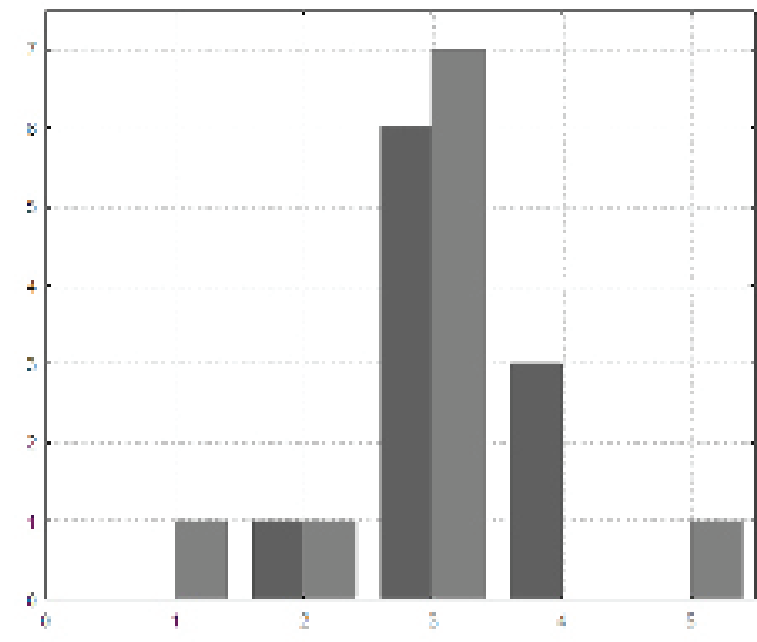

a)

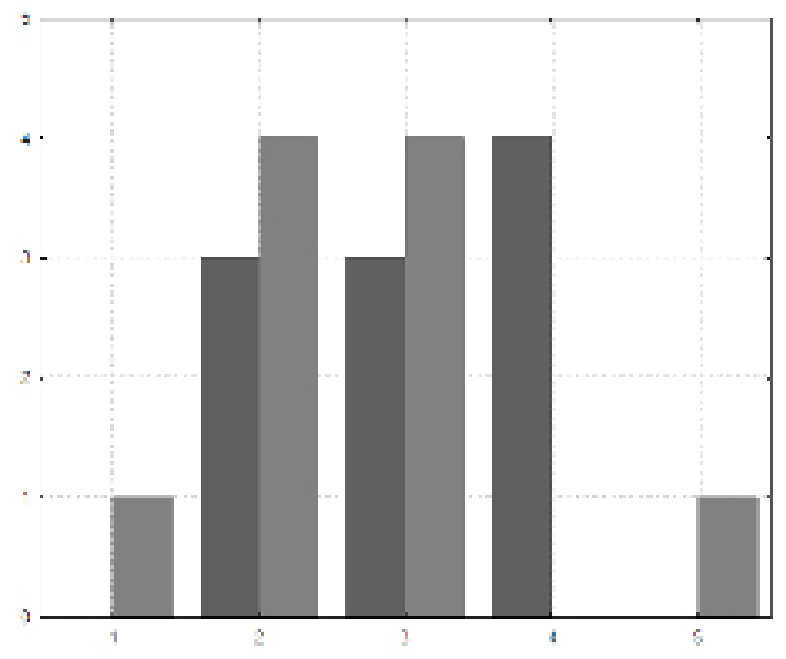

b)

Figure 4. Financial standings on a 1-5 scale (a) and investment in the employee development on a 1-5 scale (b)

In Sarajevo district $80 \%$ of the companies are exporting while in Zlatibor district that percentage amounts to $50 \%$. At the same time remaining $50 \%$ of the companies in the Zlatibor sector want to export while in the Sarajevo sector this percentage is $10 \%$.

Financial standings and investment in the employee development in small and medium sized companies of the metal industry sector in Sarajevo and Zlatibor districts

In order to release product to the foreign markets, manufacturer must deploy enough human and financial resources. Collected data on financial standings and investment in the employee development show that companies in the Zlatibor district are in a better financial condition than the ones from the Sarajevo region (table 3).

Despite the fact that the financial standings is better in the companies in the Zlatibor district (Figure 4) there is no significant difference in investment in the employee development between these two districts. Thus it can be concluded that companies from Sarajevo district focus more on the employee development.

Implementation of New Approach directives in small and medium sized companies of the metal industry sector in Sarajevo and Zlatibor districts

Every manufacturer needs to specify what EU regulations are relevant for his product. Regulations define environmental, health and safety conditions which must be fulfilled in order to release products to the EU market. Relevant regulations for industrial products are divided into:

- Area of New Approach that covers technical industrial products,

- Area of Old Approach that covers motor vehicles, as a part of metal industry [16].

In order to avoid obstacles that could come up due to the discrepancy among different national regulations, a new approach to technical regula 
tions and standardization has been made, based on the following principals [7]:

1. Prescribed key product requirements - EU directives precisely define which key requirements product must fulfill in order to be released to the EU market.

2. Harmonised standards - technical specification for the products which comply with the EU directives are delivered in the form of European harmonized standards. Compliance assumption - A product is considered to fulfill key requirements given in the directives if it is described in accordance with European harmonized standards.

3. New Approach is applied to all products which are released to the EU Single Market, regardless of whether they are produced in the member countries, or "Third World" countries (outside EU), except for the products produced in the following industrial sectors: chemical, pharmaceutical, automotive (and agricultural vehicles), and food industry.

After comparing the application of New Approach directives in different companies, the results show that there is no significant difference in choosing which directive will be implemented, between the companies of the Sarajevo and Zlatibor districts. It should be noted that most of the companies of the Zlatibor district did not have the knowledge of the New Approach directives ( $90 \%$ of them), while companies from Sarajevo district were much more aware of them (50\% of the companies) (figure 5). Comparison of implementation of New Approach directives:

- In Zlatibor district one company in the survey $(10 \%)$ uses 1 directive (Marking of packaging).

- In Sarajevo district two companies use one directive each ( Low Voltage and Machinery), while three companies use two directives each (two companies use Low Voltage Directive, one uses directive for Simple Pressure Vessels, two companies use Machinery Directive, one company uses directive Articles of precious metal and two companies use other directives). Statistically, number of implemented new approach directives in the Sarajevo district $(50 \%)$ is far greater than in Zlatibor district (10\%) (table 4).

In Sarajevo district all companies that use the New Approach also use the Directive on general product safety, and the same goes for the Zlatibor district. It can be concluded that, statistically, companies in the Sarajevo district apply the Directive on general product safety to a far greater degree compared to those from the Zlatibor district (table 5).

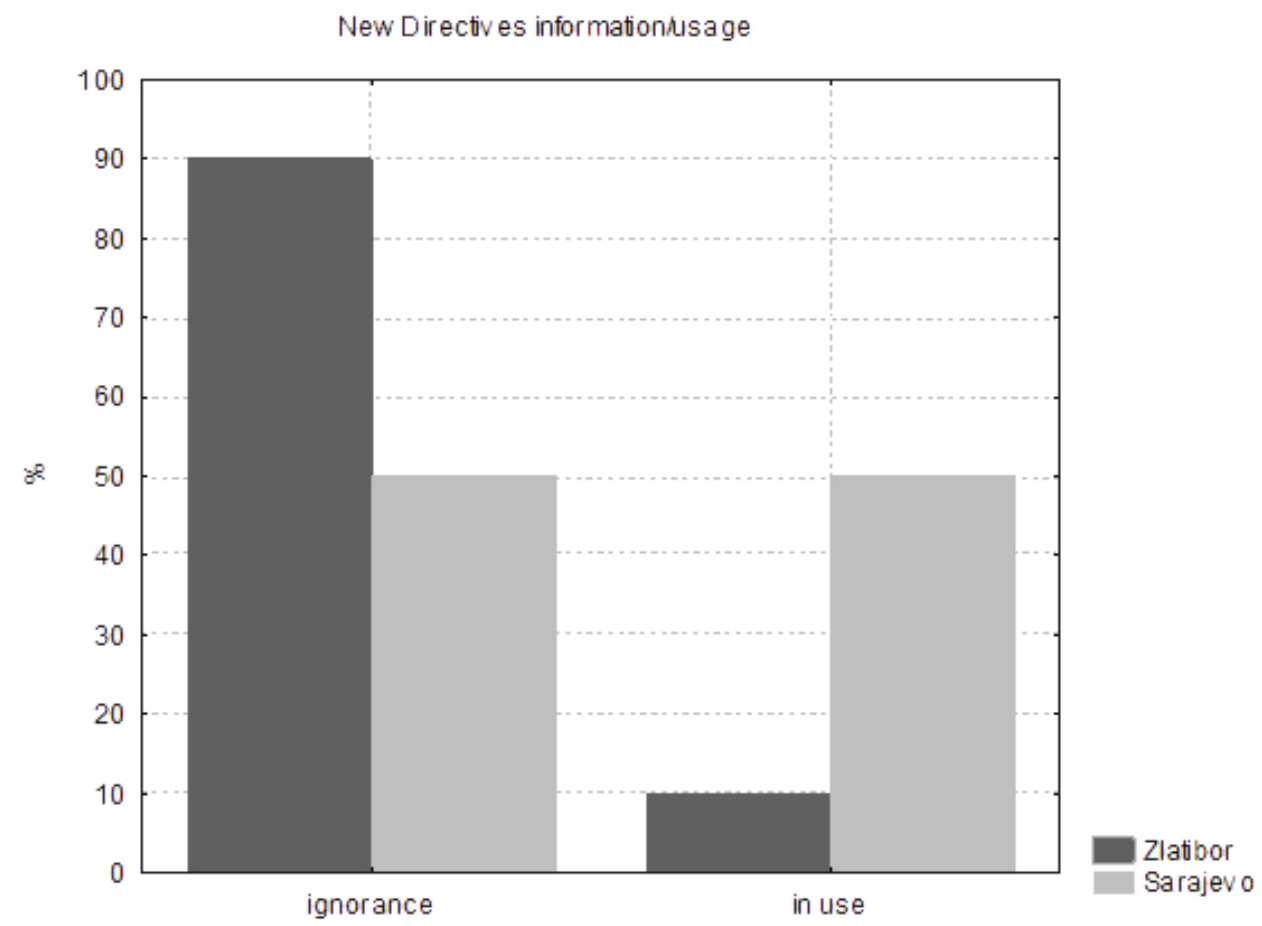

Figure 5. Knowledge of New Approach directives in Sarajevo and Zlatibor districts 
Table 4: Number of implemented New Approach directives in the Sarajevo and Zlatibor districts

\begin{tabular}{|l|l|l|l||l||l||}
\hline & ZL & & SA & & p-level \\
\hline Number of implemented deirectives & ZL & $\ll$ & SA & $* *$ & 0.0045 \\
\hline
\end{tabular}

Table 5: Number of implemented general product safety directives in the Sarajevo and Zlatibor district

\begin{tabular}{|c|c|c|c||c|c|}
\hline & ZL & & SA & & p-level \\
\hline $\begin{array}{c}\text { Number of implemented general } \\
\text { product safety directives }\end{array}$ & ZL & $<$ & SA & $* *$ & 0.0044 \\
\hline
\end{tabular}

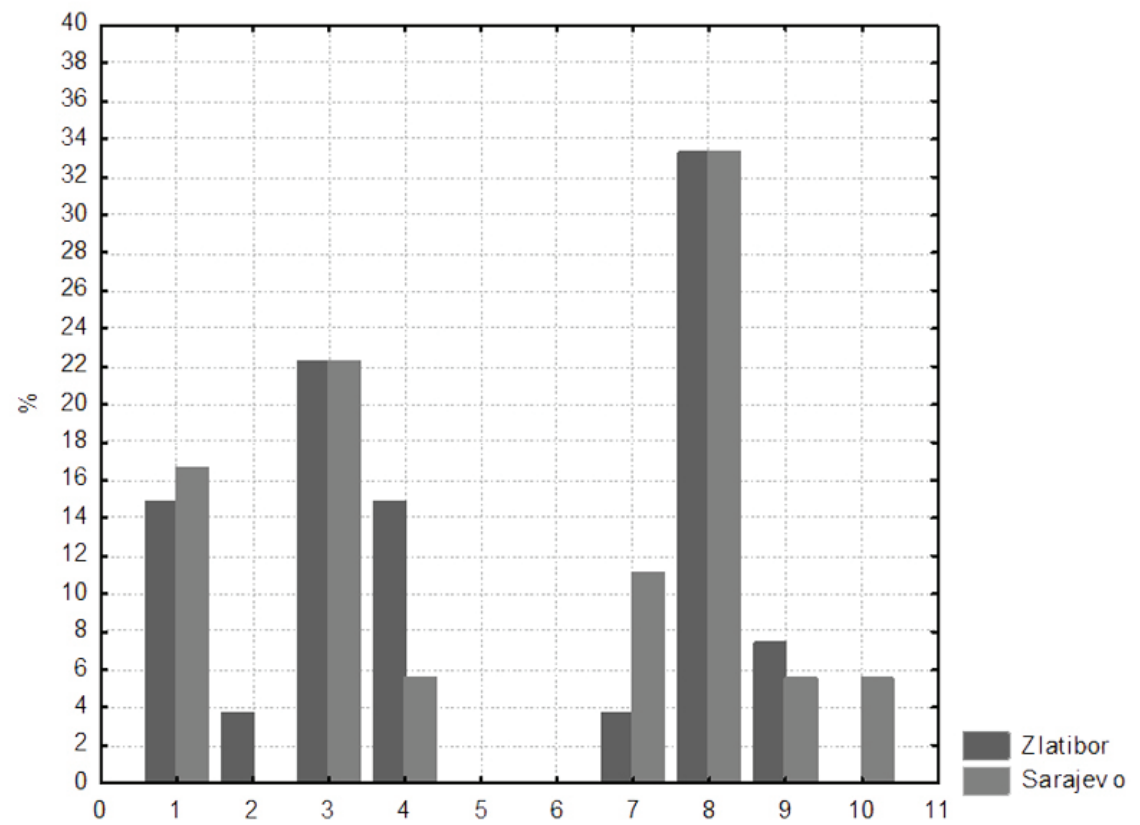

1 Government agencies, 2 Domestic embassies abroad, 3 Chamber of commerce, 4 Shipping companies, 5 Agencies for Marine Insurance, 6 Port Authority, 7 Foreign embassies and foreign economic offices, 8 Internet, 9 Banks, 10 Not collecting data - these are excluded from comparison and 11 other

Figure 6: Frequency of different sources of information used by Zlatibor and Sarajevo districts

Other observations regarding the influential parameters on fulfilling the requirements for export of metal industry products in cross border area of Serbia and BIH to EU market

In addition to the elements of survey which showed significant statistical difference, there are other aspects which influence export, and are included in the research, that need to be mentioned.

The factor of the most influence on the export of products in the Zlatibor district, is the quality needed for a given product category - 100\%, while the same factor in the Sarajevo district has the target value of $90 \%$. Fallowing are product cost, product safety and technological level of the product with $90 \%$ in the Zlatibor district and $70 \%$ in the Sarajevo district. Next are product appearance and suitable marketing with $70 \%$ in Zlatibor district, and in Sarajevo district these factors have significance of $60 \%$ and $50 \%$, respectively. Significance of factor product functionality is $70 \%$ in the Zlatibor district and $90 \%$ in the Sarajevo district.

Most of the companies in Zlatibor district (70\%) use two to three sources of information about possibilities of export to the EU market, while in the Sarajevo district, this number is greater, and divided $-50 \%$ of the companies use five sources and $40 \%$ use two.

Regarding source of information, majority of information is gathered through the internet (figure 6 ), followed by chambers of commerce and government agencies. Data is either the same or similar for both Zlatibor and Sarajevo districts. 


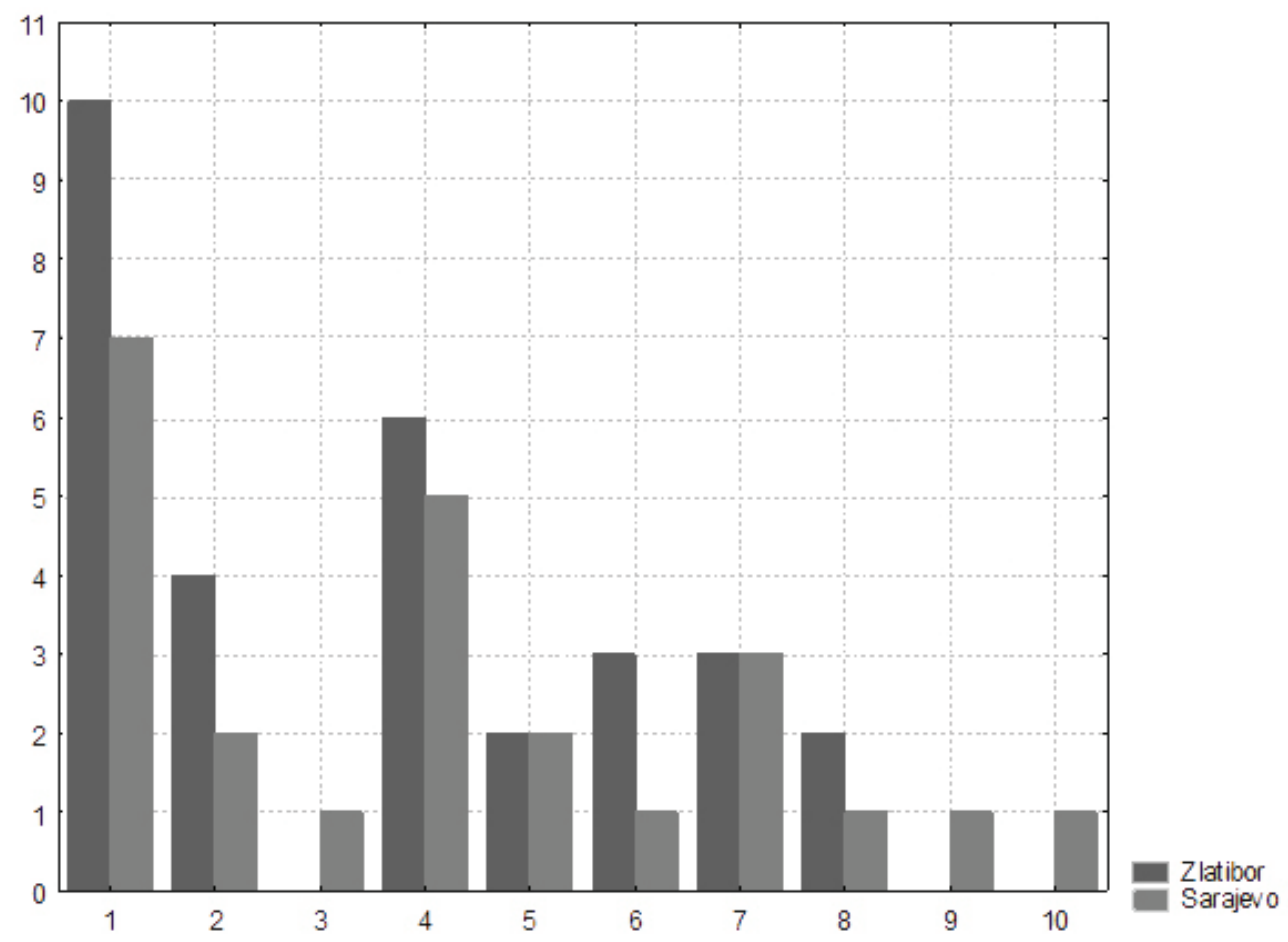

1 Demand trends, 2 Standards and specifications trends, 3 Language requirements 4 Distribution channels 6 Business practices 7 Tariff and non-tariff barriers, 8 Legal aspects (legislation), 9 Dispatching costs and 10 Other

Figure 7. Criteria for the selection of EU countries in which to export for Sarajevo and Zlatibor district

Criteria for the selection of countries in which to export suggest that for the companies most important is criterion of demand trends, followed by distribution channels. In the Zlatibor district the standards and specifications stand out as well (figure 7).

In both districts included in the research, $90 \%$ of the companies are either exporting, or want to export more than one type of product.

It is interesting to point out the conformity of components sourced from the suppliers with the EU legislation. In Sarajevo district $50 \%$ of suppliers are in conformance with EU legislation, while $30 \%$ of subsuppliers partially conform with EU legislation. As opposed to that, in case of Zlatibor district, $50 \%$ of the surveyed companies did not know the answer, and with $30 \%$ of the companies, some of suppliers were in conformance with EU legislation.

In both districts in the research, only about 30\% of companies keep track of new regulations, and the changes in the existing ones, while $40 \%$ of companies partially follows these updates.

Portion of the companies that use consulting services when fulfilling formal exporting requirements for export to the EU is $70 \%$ in Zlatibor district, and $60 \%$ in Sarajevo district.

$70 \%$ of the companies in Zlatibor district and $60 \%$ in Sarajevo district share the opinion that there is a sufficient number of suitable, registered laboratories, or competent institutions, needed for fulfilling the formal requirements for export to the EU market. As opposed to that only $40 \%$ of companies in both districts believe that there is enough number of institutions for helping the export companies.

In terms of profitability of investing resources in fulfilling the formal EU requirements for export, only $10 \%$ of the surveyed companies in the Zlatibor district consider that it is rentable to invest, while $70 \%$ considers it is not. As opposed to that, in the Sarajevo district, $60 \%$ of companies believe that such investment is rentable and $30 \%$ that it is not.

The largest issue in both Sarajevo and Zlatibor district are financial resources for fulfilling the requirements, while most influential obstacle is lack of government support and incentives.

\section{CONCLUSION}

The research on fulfilling requirements for export of metal industry products to the EU market in the cross-border area of Serbia and $\mathrm{BIH}$ gives opportunity for companies in those areas to be connected and motivated to become more competitive, by using and exchanging modern knowledge and skills, European procedures and 
standards, raising the technological level and mutual promotional appearances.

Results of this research point out the following. Companies in both districts fall under the category of small and medium sized companies, but companies in Zlatibor district have more employees. In both districts, $70 \%$ of the companies are ISO 9001 certified, while $20 \%$ are working on becoming certified. Companies in the Zlatibor district are inclined to certification in other management systems also, more than the companies in the Sarajevo district, but only $50 \%$ of surveyed companies in Zlatibor district are exporting products in EU market, as opposed to $80 \%$ of exporting companies in Sarajevo district. Despite the fact that the financial standings are better in the companies in Zlatibor district, there is no significant difference in investing in the employee development between the companies of the two districts, thus it can be concluded that companies of the Sarajevo district commit more (to the employee development. Companies in the Sarajevo district statistically implement New Approach directives much more than those in Zlatibor district. Companies in the Zlatibor district have much more problems with conformance of components sourced from suppliers with EU legislation. They are also informed from smaller number of sources than companies in the Sarajevo district. The factor with most influence on export of products in both districts is the quality needed for a given product category.

Recommendations are given to metal industry companies in both districts, based on the conducted empirical research:

- To invest more in the employee development, and to be more dependent on own employees;

- To define and describe the product and to define in which product group according to directives the product belongs to.

- Establish the date from which the directive is valid, as well as all possible changes and updates of the directive since that date;

- Since the product can belong to different directives, it is necessary to choose which directive will be the main for "CE" marking of the product, and which directives will be supporting ones;

- To define which harmonized EU regulations and standards (or certain EU member- countries that you wish to export to) apply to product;

- To define which actions regarding conformance with the main and supporting directives must be applied.

\section{ACKNOWLEDGEMENT}

This work is supported by grants TR 35017 (MESTD) and Research on formal requirements for export products on EU market in the cross border area in Bosnia and Serbia, Ref: 2012/306285/TD 11 (RRA Zlatibor).

\section{REFERENCES}

1) Albuquerque, P., Bronnenberg, B. J., Corbett, C. J., (2007) A spatiotemporal analysis of the global diffusion of ISO 9000 and ISO 14000 certification, Management science, 53(3), 451-468.

2) Alujevic-Vesnic, L., (2012) European Integration for Western Balkans: From Reconciliation to European Future, Brussels: Centre for European Studies.

3) Anders, P., (2009) Barriers to entry and market strategy: a literature review and a proposed model, European Business Review, 21(1), 64-77.

4) Anderson, S. W., Daly, J. D., Johnson., M. F., (1999) Why firms seek ISO 9000 certification: Regulatory compliance or competitive advantage?, Production \& Operations Management, 8(1), 28-43.

5) Belgrade Chamber of Commerce, (2006) Guidelines for dealing with the European Union (in Serbian), Belgrade, Serbia.

6) BIH Agency for Statistics, (2012) International trade between $\mathrm{BIH}$ and foreign countries (in Bosnian), BHAS, Sarajevo, ISSN 1840-104X.

7) Chamber of commerce and industry of Serbia, (2009) Requirements for exporting to the EU market (in Serbian), Food techology.

8) Chamber of Commerce and Industry of Serbia, (2010) 100 questions and answers for businessmen about European Union (in Serbian), ISBN 978-86-80809-80-9

9) Statistical Office of the Republic of Serbia, (2014) International trade by months from 2001 (in Serbian), URL: http://webrzs.stat.gov.rs/WebSite/Public/PageView. aspx?pKey=215

10) Chamber of Commerce and Industry of Serbia, (2013) Metal and electro industry (in 
Serbian), URL: http://www.pks.rs/PrivredaSrbije. aspx $? i d=12 \& p=2 \&$

11)Christmann, P., Taylor, G., (2001) Globalization and the environment: Determinants of firm self-regulation in China, Journal of International Business Studies, 32(3), 439-458.

12)Ćoćkalo, D., Đorđević, D., Sajfert, Z., Bogetić, S., (2011) SMEs in The Republic of Serbia: The Developing Capacities, Journal of Applied Engineering Science, 9(4), 449-456

13)Corbett, C. J., (2006) Global diffusion of ISO 9000 certification through supply chains, Manufacturing \& Service Operations Management, 8(4), 330-350.

14)Council of Ministers of Bosnia and Herzegovina, (2009) Development strategy of small and medium sized enterprises in Bosnia and Herzegovina in period 2009-2011 (in Bosnian).

15)Foreign Trade Chamber of Bosnia and Herzegovina, (2013) Strategy for export of metal sector (in Bosnian), URL: http://komorabih. ba/wp-content/uploads/2013/06/bhepa-izvozna-strategija-metalnog-sektora.pdf

16)http://www.kombeg.org.rs/Komora/centri/CentarZaEkonomskeOdnoseSalnostranstvom. aspx?ve za=3089, download from 15.10.2013.

17)Industrial Union of Serbia, (2011) Initiatives of metalworkers unions for sustainable industrial policy of Serbia (in Serbian), Towards Sustainable Industrial Policies in SEE, Seminar, Zagreb.

18)Joviševic, V., Bobrek, M., Grujic R., (2005) Standards of Europian Union for export oriented companies (in Serbian), Banja Luka. : Agencija za razvoj preduzeca.

19)Klarin, M., Milanovic, D. D., Misita, M., Spasojevic-Brkic, V., Jovovic, A., (2010) A method to assess capacity utilization in short cycle functional layouts, Proceedings of the Institution of Mechanical Engineers, Part E: Journal of Process Mechanical Engineering, 224(1), 49-58.

20)Ministry of Foreign Trade and Economic Relations of Bosnia and Herzegovina, (2012) Analysis of international trade of Bosnia and Herzegovina for 2012 (in Bosnian), Sarajevo.

21)Montgomery, D. C., Runger, G. C., (2010) Applied statistics and probability for engineers, John Wiley \& Sons.

22)Serbian Government, (2008) Strategy for development of competitive and innovative small and medium sized enterprises of the Republic of Serbia (2008-2013) (in Serbian).

23) Spasojevic Brkic, V. K., Djurdjevic, T., Dondur, N., Klarin, M. M., Tomic, B., (2013) An empirical examination of the impact of quality tools application on business performance: Evidence from Serbia, Total Quality Management \& Business Excellence, 24(5-6), 607-618.

24) Spasojevic Brkic, V. K., Klarin, M. M., Brkic, A. D., Lucanin, V. J., Milanovic, D. D., (2011) Simultaneous consideration of contingency factors and quality management: An empirical study of Serbian companies, African Journal of Business Management, 5(3), 866-883.

25)Spasojevic Brkic, V., Klarin, M., Curovic, D., (2009) Dimensions of quality management of Serbian industrial companies suppliers (in Serbian), Journal of Applied Engineering Science, 7(23-24), 67-71.

26)Spasojevic Brkic, V., Veljkovic, Z., Golubovic, T., Omic, S., Brkic, A., (2014) Bosnia and Herzegovina's metalworking industry companies barriers to export to EU market, Journal of engineering management and competitiveness (JEMC), 4(2), 78-84.

27) Stamenkovic, D., Popovic, V., SpasojevicBrkic, V., Radivojevic, J., (2011) Combination free replacement and pro-rata warranty policy optimization model, Journal of Applied Engineering Science, 9(4), 457-464.

Paper sent to revision: 03.02.2015.

Paper ready for publication: 11.03.2015. 